\title{
The defensive strike of five species of lanceheads of the genus Bothrops (Viperidae)
}

\author{
Araújo, $M S{ }^{\text {a* }}{ }^{2}$ and Martins, $M .^{\mathrm{b}}$ \\ aPrograma de Pós-Graduação em Ecologia, Instituto de Biologia, Universidade Estadual de Campinas - UNICAMP, \\ CP 6109, CEP 13083-970, Campinas, São Paulo, Brazil

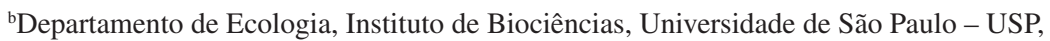 \\ CEP 05422-970, São Paulo, SP, Brazil \\ *e-mail: maraujo@unicamp.br
}

Received May 6, 2005 - Accepted June 14, 2005 - Distributed May 31, 2007

(With 2 figures)

\begin{abstract}
We studied the defensive strike of one species of each of five recognized lineages within the genus Bothrops, namely, B. alternatus, B. jararaca, B. jararacussu, B. moojeni and B. pauloensis. The defensive strike of the studied species was in general similar to that of Crotalus viridis and $C$. atrox, but some important differences were observed. Bothrops alternatus and B. pauloensis struck preferentially from a tight body posture, whereas B. jararaca and B. moojeni from a loose body posture. Defensive strikes were either true or false (during the latter, the mouth remains closed or partially open). Almost all strikes were successful; only on a few occasions snakes missed their target (flawed strikes). Strike variables were very conservative among the five species, especially strike distance and height, and one possible explanation may be related to constraints imposed on strike variables as a way of increasing strike accuracy.
\end{abstract}

Keywords: lanceheads, Bothrops, Viperidae, defensive behavior.

\section{O bote defensivo de cinco espécies de jararacas do gênero Bothrops (Viperidae)}

\section{Resumo}

Estudamos o bote defensivo de uma espécie de cada uma de cinco reconhecidas linhagens do gênero Bothrops, a saber: B. alternatus, B. jararaca, B. jararacussu, B. moojeni e B. pauloensis. O bote defensivo das espécies estudadas foi, em geral, semelhante ao de Crotalus viridis e $C$. atrox, porém algumas diferenças foram observadas. Bothrops alternatus e B. pauloensis desferiram botes preferencialmente a partir de postura corpórea enrodilhada, ao passo que $B$. jararaca e B. moojeni desferiram a maioria dos botes a partir de postura corpórea frouxa. Os botes defensivos foram verdadeiros ou falsos (nestes, a boca da serpente permaneceu fechada ou parcialmente aberta). Quase todos os botes foram bem-sucedidos; apenas em alguns casos a serpente errou o alvo (botes falhos). As variáveis relativas aos botes foram bastante conservativas entre as cinco espécies, principalmente distância e altura do bote, e uma possível explicação pode estar relacionada a restrições impostas às variáveis relativas aos botes como forma de aumentar sua acurácia.

Palavras-chave: jararacas, Bothrops, Viperidae, comportamento defensivo.

\section{Introduction}

Most knowledge of the strike of viperids is based on and limited to North-American rattlesnakes (e.g. Van Ripper, 1955; Kardong, 1986; LaDuc, 2002). Kardong (1986) compared the predatory and defensive strikes of Crotalus viridis oreganus and observed some differences between them. In the defensive strike, the snake's jaws make contact with the aggressor in a wide angle (about $180^{\circ}$ ) and the arching of the neck typical of the predatory strike was not observed. Moreover, predatory strikes were flawed sometimes, which was not observed in the defensive strike (Kardong, 1986). In another species, C. atrox, defensive strikes were reported to be faster than predatory strikes (LaDuc, 2002).
In the case of the genus Bothrops, the only reports on strike behavior are restricted to a single species, B. jararaca (Sazima, 1988, 1992). According to Sazima (1992, p. 210), "the defensive strike of B. jararaca seems similar to that reported by Kardong (1986) for Crotalus viridis", although the author does not provide any details on those similarities. In spite of similarities, defensive strikes launched during head-hiding, commonly observed in C. viridis (Kardong, 1986), were rarely observed in B. jararaca (Sazima, 1992). In comparing the defensive strike of $B$. jararaca to those of other congeneric species, Sazima (1988) suggested that the strike of $B$. jararaca is slower than that of $B$. moojeni and 
B. neuwiedi urutu, but his suggestion remains untested until the time of writing.

Phylogenetic relationships within the Brazilian species of the genus Bothrops revealed the existence of six distinct lineages, namely, the alternatus, atrox, jararaca, jararacussu, neuwiedi and taeniatus species groups (Salomão, et al. 1997, Vidal et al., 1997, Wüster et al., 2002). As part of a study on the evolution of defensive behaviorin each of five lineages within the genus Bothrops, we compared features of the defensive strike between one species of each lineage, namely, B. alternatus (alternatus group); B. jararaca (jararaca group); B. jararacussu (jararacussu group); B. moojeni (atrox group); and finally $B$. pauloensis (neuwiedi group).

\section{Material and Methods}

Test subjects were species of Bothrops from several localities of southeastern $\left(45^{\circ} 21^{\prime}-50^{\circ} 11^{\prime} \mathrm{W}\right.$ and $19^{\circ}$ $18^{\prime}-24^{\circ} 41^{\prime}$ 'S B B. alternatus, B. jararaca, B. jararacussu, $B$. pauloensis, and B. moojeni) and central Brazil (47 $56^{\prime}-53^{\circ} 31^{\prime} \mathrm{W}$ and $16^{\circ} 56^{\prime}-18^{\circ} 9^{\prime} \mathrm{S}$; B. moojeni) brought to the Instituto Butantan from April 1998 through February 1999. Ten individuals of each species were tested as they arrived at the Instituto Butantan (Table 1). The time between the arrival of the snakes at the Instituto Butantan and the tests varied from zero (tests on the same day of arrival) to 16 days for all individuals tested, except for an individual of $B$. jararacussu that was kept for 33 days at the Instituto Butantan before tests were performed.

Each individual snake was tested only once. Snakes were held at the Instituto Butantan in wooden or plastic boxes until the actual tests. They were taken in wooden boxes to a temperature-controlled laboratory $\left(25^{\circ} \mathrm{C} \pm 2\right)$ where the trials were conducted. The snakes were taken to the laboratory during daytime and each trial was carried out on the same day from 1800 hours to 0000 hours.

The trials were carried out in an arena set on the ground of the laboratory (Figure 1). The laboratory wall formed one of the sides of the arena; the other three sides were made of wood and glass (Figure 1). One of the sides adjacent to the wall was opaque and the other two sides were transparent. During trials, we stayed behind the opaque side of the arena to minimize possible disturbance. Two Panasonic NVRJ PR VHS cameras were used, one over the arena set on a tripod and facing

Table 1. Sizes (mm) and number of individuals of the five species of Bothrops studied. SVL: snout-vent length; SD: standard deviation; and $\mathrm{N}=$ number of individuals.

\begin{tabular}{lcclc}
\hline \multicolumn{1}{c}{ Species } & Mean SVL & \multicolumn{1}{c}{ SD } & \multicolumn{1}{c}{ Range } & N \\
\hline B. alternatus & 708.6 & 160.35 & $636-1025$ & 10 \\
B. jararaca & 803.2 & 169.86 & $465-1050$ & 10 \\
B. jararacussu & 611.1 & 187.13 & $430-840$ & 10 \\
B. moojeni & 946.5 & 137.48 & $740-1175$ & 10 \\
B. pauloensis & 608.0 & 126.23 & $385-865$ & 10 \\
\hline
\end{tabular}

the ground, and the other on the ground, lateral to the arena and facing the wall. The ground was covered with a black plastic sheet; both the plastic sheet and the wall had gridlines of 1 and $2 \mathrm{~cm}$, respectively, for distance estimates. The light sources were two 60-Watt bulbs set on the main axis of the arena, one at each side. During the tests, we stayed behind the opaque side, which we believe further reduced the possibility of our being seen by the snake.

Defensive behavior was elicited with the use of a stimulation-object, a plastic bottle (height about $15 \mathrm{~cm}$; diameter about $10 \mathrm{~cm}$; volume 0.51 ) covered with a $0.5 \mathrm{~cm}$-thick sheet of soft black rubber to which a 1.5 -meter plastic pipe was attached at a $45^{\circ}$ angle (Figure 2e, f). The purpose of the rubber was to minimize injuries on the snakes' fangs during strikes. The bottle was filled with warm water $\left(60^{\circ} \mathrm{C}\right)$ shortly before the tests to raise the temperature of the external surface of the rubber to about $37{ }^{\circ} \mathrm{C}$ (verified by a Miller and Weber Inc. quick-reading thermometer with accuracy of $0.1{ }^{\circ} \mathrm{C}$ ), in an attempt to simulate the body temperature of a mammal, a putative predator of lanceheads (Sazima, 1992).

Before each test, the internal surfaces of the arena as well as the stimulation-object were cleaned with ethanol. The snake was then put in the center of the arena and a

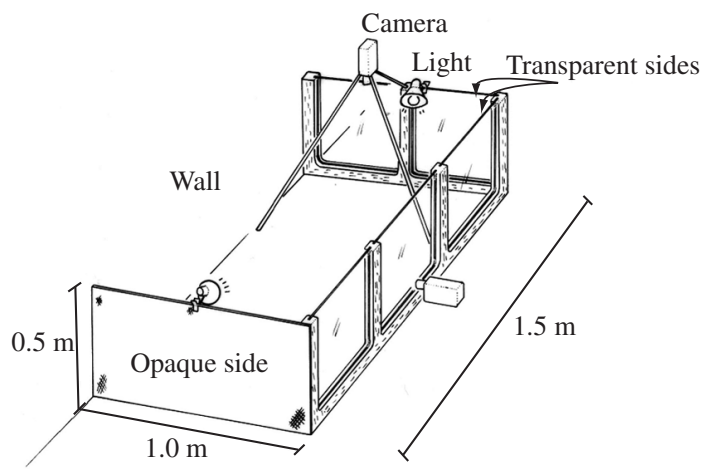

Figure 1. Arena where the defensive strikes of five species of Bothrops were elicited and filmed.
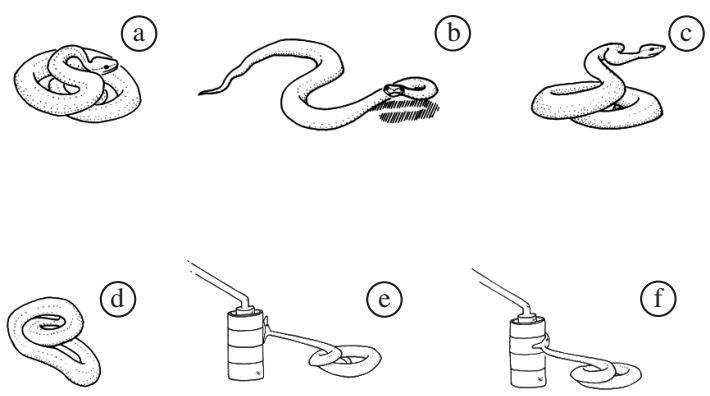

Figure 2. a) Bothrops spp. in tight body posture; b) loose body posture; c) head-elevated posture; d) head-hiding posture; e) typical defensive strike, with stimulation-object being hit frontally; and f) lateral defensive strike, with stimulation-object being hit in a lateral position. 
transparent acrylic box $(30 \mathrm{~cm}$ each side and height of $15 \mathrm{~cm}$ ) with the open side facing down, was put over the snake with the use of a hook. The acrylic box was also cleaned with ethanol before the tests. The arena lights were on prior to introducing snakes into the arena. Snakes were left undisturbed for 10 minutes before the beginning of the tests.

Cameras were turned on by remote control and recorded at 30 frames/s. Trials began when the acrylic cover was removed with a hook and the stimulationobject was introduced into the arena, about $0.7 \mathrm{~m}$ far from the snake, and moved in the air (c. $1 \mathrm{~cm}$ above ground) towards the snake, at approximately $20 \mathrm{~cm} \cdot \mathrm{s}^{-1}$, always by the same person. The stimulation-object was moved in the main axis of the arena and approached the snake frontally, touched the snake's midbody and was withdrawn repeatedly 30 times uninterruptedly for each snake. During trials, we never moved from behind the light bulb. Trials were later analyzed frame-by-frame with a Panasonic NVSD475 PR VHS player.

The following variables of strikes were analyzed: 1) distance, estimated as the distance between the snake's snout at the beginning of the strike and when it made contact with the stimulation-object; 2) height, estimated as the height of the snake's snout in relation to the ground when it made contact with the stimulation-object; 3 ) angle between the ground and a line crossing the position of the snake's snout at the beginning of the strike and when it made contact with the stimulation-object; 4) duration, estimated as the number of frames from the beginning of the strike until contact with the stimulationobject multiplied by $1 / 30 \mathrm{~s}$ (which corresponds to one frame); and 5) speed, estimated as the strike distance divided by its duration.

On certain occasions, the snake allowed the stimulation-object to touch its body before launching a strike; at this moment the snake opened its mouth and the jaws were brought to bear on the stimulation-object with no projection of the head. Although these attacks by the snake may be considered strikes, we did not include them in the analyses since they did not involve the typical projection of the head observed in the other strikes. Strikes in which jaws were wide open and contact was made with the stimulation-object were recorded as "true strikes", whereas those in which the mouth remained closed or only partially open during strike were recorded as "false strikes" (cf. Greene, 1988; Sazima, 1992). On a few occasions, the snake completely missed the target, which was recorded as a "flawed strike" (cf. Kardong, 1986). At the moment of the strike, the snake's body was either in a tight posture, that is, with more acute body angles (Figure 2a) or in a loose posture, with anterior body angles more open and less acute (Figure 2b). The depicted postures (Figure 2a, b) actually represent extremes of a continuum in which snakes could change from one posture to the other during trials. Therefore, the classification of body posture at the moment of the strike in either tight or loose was totally arbitrary. Sometimes strikes were delivered from head-elevated postures (Figure 2c) and on other occasions from head-hiding postures (Figure 2d). The frequencies of occurrence of strike types, as well as body postures and concomitant behaviors during strike delivery were compared among species with a $\mathrm{G}$ test (Zar, 1999).

For comparisons among species, the distances and heights of the strikes were divided by the snout-vent length (SVL) of each individual, because the species studied differ greatly in size (Table 1). When an individual struck more than once during the trial, a mean value of all its strikes was calculated for each variable. These mean values were used in the comparisons among species, so that the independent units of the data were no longer the strikes but the mean values assigned to each individual. The variables were compared among species by Kruskal-Wallis ANOVA (Zar, 1999). Statistical analyses were performed with BIOESTAT 3.0 (G test; Ayres and Ayres, 2003) and STATISTICA 6.1 (Kruskal-Wallis ANOVA; StatSoft, 2003).

\section{Results}

The typical defensive strike recorded for the five species was a rapid movement of the snake's head towards the stimulation-object, as the lateral curves of its anterior body straightened, with its jaws wide-open and the posterior part of the body remaining stationary. During this phase, rapid acceleration towards the stimulation-object was observed. On contact with the stimulation-object, the jaws formed an angle of about $180^{\circ}$ and no arching of the neck was observed (Figure 2e). We were not able to register the penetration of the snake's fangs into the rubber of the stimulation-object (bite) through the analysis of the films. However, it certainly occurred, because the rubber always presented marks of perforation from which venom drained following the tests.

Sometimes the snake launched what is here called a lateral strike, in which its head rotated around the long axis of the anterior trunk $90^{\circ}$ during the strike and the stimulation-object was hit at a lateral position (Figure 2f), instead of being hit frontally, as occurred in the typical strike. This lateral strike was a marked difference between the strike behavior of $B$. pauloensis and that of the other species ( $\mathrm{G}$ test, $\mathrm{df}=4, \mathrm{G}=83.63, \mathrm{P}<0.001$; Table 2). Species differed in the frequencies of false strikes ( $\mathrm{G}$ test, $\mathrm{df}=4, \mathrm{G}=27.01, \mathrm{P}<0.001$; Table 2), and flawed strikes ( $\mathrm{G}$ test, $\mathrm{df}=4, \mathrm{G}=12.42, \mathrm{P}=0.01$; Table 2), as well as tight/loose body postures during strikes ( $\mathrm{G}$ test, $\mathrm{df}=4, \mathrm{G}=20.82, \mathrm{P}<0.001$; Table 3). Bothrops moojeni launched most of its strikes from head-elevated postures ( $\mathrm{G}$ test, $\mathrm{df}=4, \mathrm{G}=82.81, \mathrm{P}<0.001$; Table 3 ), and all five species rarely struck while hiding the head (Table 3).

Strikes were on average short and low when considering either the raw values of distance and height or their values in relation to the snakes' SVL (Table 4). There were no significant differences among species in any of the variables, except in strike angle $(\mathrm{H}=13.865$; $\mathrm{P}=0.008 ; \mathrm{N}=41 ;$ Table 4 ). 
Table 2. The different types of defensive strike in five species of Bothrops shown as percentages of total number of strikes (number of strikes in parenthesis). $*$, *** $=$ difference significant; $*(\mathrm{P}<0.05)$, *** $(\mathrm{P}<0.001)$.

\begin{tabular}{|c|c|c|c|c|c|}
\hline \multirow[t]{2}{*}{ Species } & \multicolumn{2}{|c|}{ Strike type $\mathbf{I}^{* * *}$} & \multicolumn{2}{|c|}{ Strike type $\mathbf{I I} * * *$} & \multirow{2}{*}{$\begin{array}{c}\text { Strike type III* } \\
\text { Flawed }\end{array}$} \\
\hline & Frontal & Lateral & True & False & \\
\hline B. alternatus & $100.0(60)$ & $0(0)$ & $95.0(57)$ & $5.0(3)$ & $5.0(3)$ \\
\hline B. jararaca & $98.4(65)$ & $1.6(1)$ & $95.5(63)$ & $4.5(3)$ & $7.6(5)$ \\
\hline B. jararacussu & $100.0(58)$ & $0(0)$ & $74.1(43)$ & $25.9(15)$ & $8.6(5)$ \\
\hline B. moojeni & $98.9(92)$ & $1.1(1)$ & $94.6(88)$ & $5.4(5)$ & 0 \\
\hline B. pauloensis & $54.2(26)$ & $45.8(22)$ & $75.0(36)$ & $25.0(12)$ & $2.1(1)$ \\
\hline
\end{tabular}

Table 3. Body postures or concomitant behaviors at the moment strikes were launched in five species of Bothrops shown as percentages of total number of strikes (number of strikes in parenthesis). $* * *=$ difference significant $(\mathrm{P}<0.001)$.

\begin{tabular}{|c|c|c|c|c|}
\hline \multirow[t]{2}{*}{ Species } & \multicolumn{2}{|c|}{ Body posture I*** } & \multirow{2}{*}{$\begin{array}{c}\text { Body posture II } * * * \\
\text { Head elevated } \\
\end{array}$} & \multirow{2}{*}{$\begin{array}{c}\text { Concomitant behavior } \\
\text { Head hidden } \\
\end{array}$} \\
\hline & Tight & Loose & & \\
\hline B. alternatus & $58.6(34)$ & $41.4(24)$ & $5.0(3)$ & $3.3(2)$ \\
\hline B. jararaca & 29.7 (19) & $70.3(45)$ & $15.2(10)$ & $1.5(1)$ \\
\hline B. jararacussu & $47.1(24)$ & $52.9(27)$ & $8.5(5)$ & $1.7(1)$ \\
\hline B. moojeni & $39.7(31)$ & $60.3(47)$ & $60.2(56)$ & 0 \\
\hline B. pauloensis & $68.2(30)$ & $31.8(14)$ & 22.9 (11) & $4.2(2)$ \\
\hline
\end{tabular}

Table 4. Recorded variables of the defensive strike of five species of Bothrops shown as medians, quartiles (in parentheses) and $\mathrm{N}=$ number of strikes (see text for explanation on the independent units of the data). SVL $=$ snout-vent length; $*=$ difference significant $(\mathrm{P}<0.05)$; different letters $(\mathrm{a}$ and $\mathrm{b})$ indicate significant difference in the a posteriori test.

\begin{tabular}{cccccc}
\hline Variable & B. alternatus & B. jararaca & B. jararacussu & B. moojeni & B. pauloensis \\
\hline Distance $(\mathrm{cm})$ & $10.1(8.8-11.1)$ & $11.1(7.4-12.8)$ & $8.7(6.7-12.8)$ & $12.6(8.7-13.9)$ & $10.9(9.1-12.2)$ \\
& $\mathrm{N}=10$ & $\mathrm{~N}=8$ & $\mathrm{~N}=8$ & $\mathrm{~N}=10$ & $\mathrm{~N}=7$ \\
Height $(\mathrm{cm})$ & $9.2(6.1-10.4)$ & $9.8(9.3-11.1)$ & $6.8(6.3-7.7)$ & $12.1(11.0-14.3)$ & $7.3(5.8-10.0)$ \\
& $\mathrm{N}=10$ & $\mathrm{~N}=8$ & $\mathrm{~N}=9$ & $\mathrm{~N}=10$ & $\mathrm{~N}=7$ \\
Distance/SVL & $0.14(0.11-0.17)$ & $0.13(0.11-0.16)$ & $0.17(0.15-0.19)$ & $0.12(0.10-0.16)$ & $0.15(0.13-0.22)$ \\
& $\mathrm{N}=10$ & $\mathrm{~N}=8$ & $\mathrm{~N}=8$ & $\mathrm{~N}=10$ & $\mathrm{~N}=7$ \\
Height/SVL & $0.12(0.08-0.16)$ & $0.11(0.11-0.13)$ & $0.12(0.11-0.15)$ & $0.13(0.12-0.15)$ & $0.12(0.10-0.13)$ \\
& $\mathrm{N}=10$ & $\mathrm{~N}=8$ & $\mathrm{~N}=9$ & $\mathrm{~N}=10$ & $\mathrm{~N}=7$ \\
Angle* $\left({ }^{\circ}\right)$ & $40.5^{\mathrm{ab}}(35.3-45.5)$ & $48.7^{\mathrm{b}}(43.6-52.8)$ & $40.7^{\mathrm{ab}}(39.0-47.2)$ & $32.5^{\mathrm{a}}(31.0-34.0)$ & $39.8^{\mathrm{a}}(34.8-43.0)$ \\
& $\mathrm{N}=10$ & $\mathrm{~N}=8$ & $\mathrm{~N}=8$ & $\mathrm{~N}=9$ & $\mathrm{~N}=6$ \\
Duration $(\mathrm{ms})$ & $80.6(66.7-110.0)$ & $93.9(72.2-123.5)$ & $100.0(76.4-113.0)$ & $117.9(100.0-133.3)$ & $100.0(100.0-104.5)$ \\
& $\mathrm{N}=10$ & $\mathrm{~N}=8$ & $\mathrm{~N}=8$ & $\mathrm{~N}=10$ & $\mathrm{~N}=7$ \\
Speed $\left(\mathrm{cm} . \mathrm{s}^{-1}\right)$ & $123.0(110.7-131.4)$ & $120.2(100.7-134.0)$ & $99.6(78.1-124.8)$ & $101.0(95.7-113.7)$ & $109.3(89.6-111.2)$ \\
& $\mathrm{N}=10$ & $\mathrm{~N}=8$ & $\mathrm{~N}=8$ & $\mathrm{~N}=10$ & $\mathrm{~N}=7$ \\
\hline
\end{tabular}

\section{Discussion}

The defensive strikes observed in our study had the same overall "stabbing" appearance of those described for C. viridis (Kardong, 1986) and C. atrox (LaDuc, 2002), as opposed to the "biting" appearance of the predatory strike. We agree with LaDuc (2002) that this may result from the large or awkwardly sized targets used in studies of defensive strikes (Kardong, 1986; LaDuc, 2002; this study). This fact may also be responsible for the lack of dorsal neck arching in the five species studied herein. Kardong (1986) suggested that the unarching of the neck in defensive strikes could lead to "dry" bites, with little or no envenomation. This seems not to be true for the five species of Bothrops studied, since no arching of the neck was observed, but still we could always detect the presence of venom draining from the surface of the stimulation-object following trials, sometimes in large amounts, indicating successful envenomation.

The studied Bothrops species very rarely launched strikes from head-hiding postures (Table 3), which seems to be an important difference between the striking behavior of lanceheads and that of $C$. viridis (Duvall et al., 1985) and C. atrox (M. Martins, pers. obs.). In fact, Sazima (1992) had already noticed the rarity of this behavior in B. jararaca and pointed to this as an 
important difference between $B$. jararaca and $C$. viridis. The strikes of the five species of Bothrops were on average shorter than 0.20 of the snake's SVL (Table 4) and never longer than one third of it. This is another difference between the studied lanceheads and $C$. atrox, as the defensive strikes of the latter reached $37 \%$ of the snake's total length on average and a maximum of $46 \%$ (LaDuc, 2002). The five Bothrops species presented much slower strikes (Table 4) than those of $C$. viridis and C. atrox; the defensive strike of $C$. viridis had an average speed of $243 \mathrm{~cm} . \mathrm{s}^{-1}$ (Van Riper, 1955), and that of C. atrox an average of $227 \mathrm{~cm} . \mathrm{s}^{-1}$ (LaDuc, 2002). The duration of the strikes as defined herein can be compared to that of the extend stage of the defensive strikes of $C$. atrox as defined by LaDuc (2002); in the five species of Bothrops, the duration was longer (Table 4) than in $C$. atrox $(42-70 \mathrm{msec} ;$ mean $=50 \mathrm{msec} ;$ LaDuc, 2002), which is surprising in view of the shorter strike-distances in Bothrops spp., and probably due to the lower speed in the five Bothrops species compared to that in C. atrox. LaDuc (2002) observed that the defensive strikes were longer and faster than the predatory strikes of $C$. atrox, but Young et al. (2001; cited in LaDuc, 2002) reports exactly the opposite, which renders this question controversial. The study of the characteristics of the predatory strikes of the five species of Bothrops studied would be of great interest, and could help to clarify this question.

The recorded strikes were very similar in general aspect to those described by Sazima $(1988,1992)$ for B. jararaca in the field. The exception was B. pauloensis, whose strikes were frequently launched laterally (Table 2). This is a remarkable difference between $B$. pauloensis and the other species studied here. Only $B$. moojeni and $B$. jararaca did also present this type of strike, but much less frequently than B. pauloensis. It is possible that this strike behavior is also present in other species of the neuwiedi group, which needs further investigation. Most defensive strikes in the five species of Bothrops were successful, and flawed strikes were a relatively rare event (Table 2). Shine et al. (2002) report a much lower accuracy in the defensive strike of another viperid, Gloydius shedaoensis (46.7\% of flawed strikes). Hence, there seems to be great variation in the accuracy of strikes between different lineages of vipers.

In spite of the difference between the defensive strike behavior of B. pauloensis and the other studied species, the studied variables were impressively conservative among the five species studied, especially strike distance and height (as related to SVL). Strike speed did not differ significantly among the five species of lanceheads studied, so the suggestion that the strikes of $B$. jararaca seem to be slower than those of B. moojeni (Sazima, 1992) was not supported by this study (Table 4). The only exception among variables seems to be strike angle, which was significantly different among species (Table 4). The extremely low angles in B. moojeni, in comparison with the other studied species, were certainly due to the fact that the former launched strikes preferentially from elevated body postures. If snakes somehow define the angle of strike as a way of hitting a certain height on the target, individuals of B. moojeni can hit the same height even with low strike-angles, because in a head-elevated posture the head is already high when strikes are delivered. In this sense, the angles recorded for B. moojeni may introduce some noise in the comparisons among species. If B. moojeni is removed from the comparisons, however, there is no difference in the strike angles of the remaining four species $(\mathrm{H}=5.666 ; \mathrm{P}=0.13 ; \mathrm{N}=31)$.

According to Kardong and Smith (2002), the predatory success of rattlesnakes depends on an accurate strike that produces no significant errors in fang placement, penetration, and venom injection. In the case of defensive strikes, evolution must have also placed a premium on accuracy, which may have imposed constraints on some of their kinematic features, making strikes resistant to variation. This might be one explanation for the high similarity between the strikes of the five studied species, and further studies on a higher number of species of the different lineages of Bothrops could confirm this pattern. It is possible that strike variables are also very conservative among species of the genus Crotalus, which could also be investigated by a comparative study of the strikes of rattlesnakes.

Acknowledgments - We are grateful to the Instituto Butantan for providing the snakes studied and to the members of staff, J. Cavalheiro (Seu Quim), F. L. Franco, V. J. Germano and O. A. V. Marques, who kindly separated the snakes used. L. dos Anjos, N. L. Hülle, O. A. V. Marques, C. Nogueira, R. Nunes, J. L. de Oliveira, and R. J. Sawaya helped in laboratory work. P. R. Guimarães Jr. helped with statistics. We are indebted to R. L. Fonseca for providing the geographic coordinates of localities. O. A. V. Marques, R. J. Sawaya and I. Sazima critically read the manuscript. An anonymous referee made useful suggestions. MSA had financial support from CAPES and FAPESP (97/12222-3 and 98/02307-4). MM thanks FAPESP for grants (95/09642-5 and 00/12339-2) and CNPq for a fellowship.

\section{References}

AYRES, M. and AYRES Jr., M., 2003. BioEstat 3.0: aplicações estatísticas nas áreas das ciências biológicas e médicas. Sociedade Civil Mamirauá, Belém; CNPq, Brasília.

DUVALL, D., KING, MB. and GUTZWILLER, KJ., 1985. Behavioral ecology and ethology of the prairie rattlesnake. Nat. Geogr. Res., vol. 1, p. 80-111.

GREENE, HW., 1988. Antipredator mechanisms in reptiles, In GANS, C. and HUEY, RB (eds.), Biology of the Reptilia, Alan R. Liss, Inc., New York, p. 1-152.

KARDONG, KV., 1986. The predatory strike of the rattlesnake: when things go amiss. Copeia, no. 3, p. 816-820.

KARDONG, KV. and BELS, VL., 1998. Rattlesnake strike behavior: kinematics. J. exp. Biol., vol. 201, p. 837-850.

KARDONG, KV. and SMITH, TL., 2002. Proximate factors involved in rattlesnake predatory behavior: a review, In SCHUETT, GW., HÖGGREN, M., DOUGLAS, ME and GREENE, HW (eds.), Biology of the Vipers, Eagle Mountain Publishing, Eagle Mountain, p. 253-266. 
LADUC, TJ., 2002. Does a quick offense equal a quick defense? Kinematic comparisons of predatory and defensive strikes in the western diamond-backed rattlesnake (Crotalus atrox), In SCHUETT, GW. HÖGGREN, M., DOUGLAS, ME. and GREENE, HW (eds.), Biology of the Vipers, Eagle Mountain Publishing, Eagle Mountain, p. 267-278.

SALOMÃO, MG., WÜSTER, W., THORPE, RS., and TOUZET, JM., BBBSP, 1997. DNA evolution of South American pitvipers of the genus Bothrops (Reptilia: Serpentes: Viperidae), In THORPE, RS., WÜSTER, W. and MALHOTRA A (eds.), Venomous Snakes: Ecology, Evolution and Snakebite, Oxford University Press Inc., New York, p. 89-98.

SAZIMA, I., 1988. Um estudo da biologia comportamental da jararaca, Bothrops jararaca, com uso de marcas naturais. Mem. Inst. Butantan, vol. 50, no. 3, p. 83-99.

-, 1992. Natural history of the jararaca pitviper, Bothrops jararaca, in southeastern Brazil, In CAMPBELL, JA. and BROODIE Jr., ED (eds.), Biology of the Pitvipers, Selva Publ., Tyler, p. 199-216.

SHINE, R., LI-XIN, S., FITZGERALD, M. and KEARNEY, M., 2002. Antipredator responses of free-ranging pit vipers (Gloydius shedaoensis, Viperidae). Copeia, no. 3, p. $843-850$.
STATSOFT, 2003. STATISTICA for Windows, Release 6.1. StatSoft, Inc., Tulsa.

VAN RIPER, W., 1955, How a rattlesnake strikes. Nat. Hist., vol. 64 , p. 308-311.

VIDAL, N., LECOINTRE, G., VIÉ, JC. and Gasc, JP., 1997. Molecular systematics of pitvipers: paraphyly of the Bothrops complex. C. R. Acad. Sci. Paris, vol. 320, p. 95-101.

WÜSTER, W., SALOMÃO, MG. and QUIJADAMASCAREÑAS, JA., and Thorpe, RS., BBBSP, 2002. Origins and evolution of the South American pitviper fauna: evidence from mitocondrial DNA sequence analysis, In SCHUETT, GW., HÖGGREN, M., DOUGLAS, ME. and GREENE, HW (eds.), BiologyoftheVipers, EagleMountainPublishing,EagleMountain, p. 111-128.

YOUNG, BA., PHELAN, M., JAGGERS, J. and NEJMAN, N., 2001. Kinematic modulation of the strike of the western diamondback rattlesnake (Crotalus atrox). Hamadryad, vol. 26, p. 288-321.

ZAR, JH., 1999. Biostatistical analysis. Prentice-Hall, Inc., Upper Saddle River, $4^{\text {th }}$ ed. 